\title{
THE IMPACT OF COVID-19 EPIDEMIOLOGICAL RESTRICTION GUIDELINES MEASURES IN A CROATIAN TERTIARY COLORECTAL CANCER CENTER
}

\author{
IVA KIRAC ${ }^{1}$, ZVONIMIR MISIR ${ }^{2}$, VESNA VORIH ${ }^{1}$, LORIS ĆURT ${ }^{3}$, \\ MARIO ŠEKERIJA ${ }^{4}$ and NATAŠA ANTOLJAK ${ }^{5}$ \\ ${ }^{1}$ Department of Surgical Oncology, University Hospital for Tumors, \\ Sestre milosrdnice University Hospital Center, Zagreb, Croatia; \\ ${ }^{2}$ Department of Upper Gastrointestinal Surgery, \\ Sestre milosrdnice University Hospital Center, Zagreb, Croatia; \\ ${ }^{3}$ Department of Emergency Medicine Sisak County, Sisak, Croatia; \\ ${ }^{4}$ Croatian National Cancer Registry, Croatian Institute of Public Health, Zagreb, Croatia; \\ ${ }^{5}$ School of Medicine, University of Zagreb and Croatian Institute of Public Health, \\ School of Public Health Andrija Štampar, Zagreb, Croatia
}

\section{Summary}

Background: In the past six months, Croatia faced a short lockdown and a slow return to most hospitals' everyday activities. During the lockdown, our center, as a part of the University Hospital Centre specialized for solid cancer, was enabled to maintain most of the routine practices with the one-month colonoscopy exception.

Aim: To determine the oscillation in the number of endoscopies and colorectal surgery for 13 months (six months pre and post COVID-19 lockdown).

Materials and methods: From August 1st, 2019, until August 31st 2020, the hospital analytics determine the number of colonoscopies, screening colonoscopies, and surgeries.

Results: During the given period number of detected and operated colorectal cancers was stable, except for April, when we mostly did not perform colonoscopies.

Conclusion: We maintained a pre-COVID-19 pace in colorectal cancer treatment, colonoscopies, and colorectal surgery after epidemiological guidelines for colonoscopies and colorectal surgery were applied, owing to the relatively stable overall epidemiological situation.

KEYWORDS: colorectal surgery, colonoscopy, COVID-19, Croatia

\section{INTRODUCTION}

Colorectal cancer remains a considerable cancer burden in Croatia due to high incidence,

Corresponding author: Iva Kirac, Department of Surgical Oncology, University Hospital for Tumors, Sestre milosrdnice University Hospital Center, Ilica 197, 1000 Zagreb, Croatia.

e-mail: iva.kirac@kbcsm.hr late discovery, and poor survival according to the European standards(1). The COVID-19 pandemic situation decreased the accessibility and routes for colorectal cancer screening in many European countries, causing endoscopy performance to stop in most Croatian healthcare facilities disabling an EU quality assurance guidelines satisfactory response of $45 \%$, unlikely to achieve desirable $65 \%(2,3)$. 


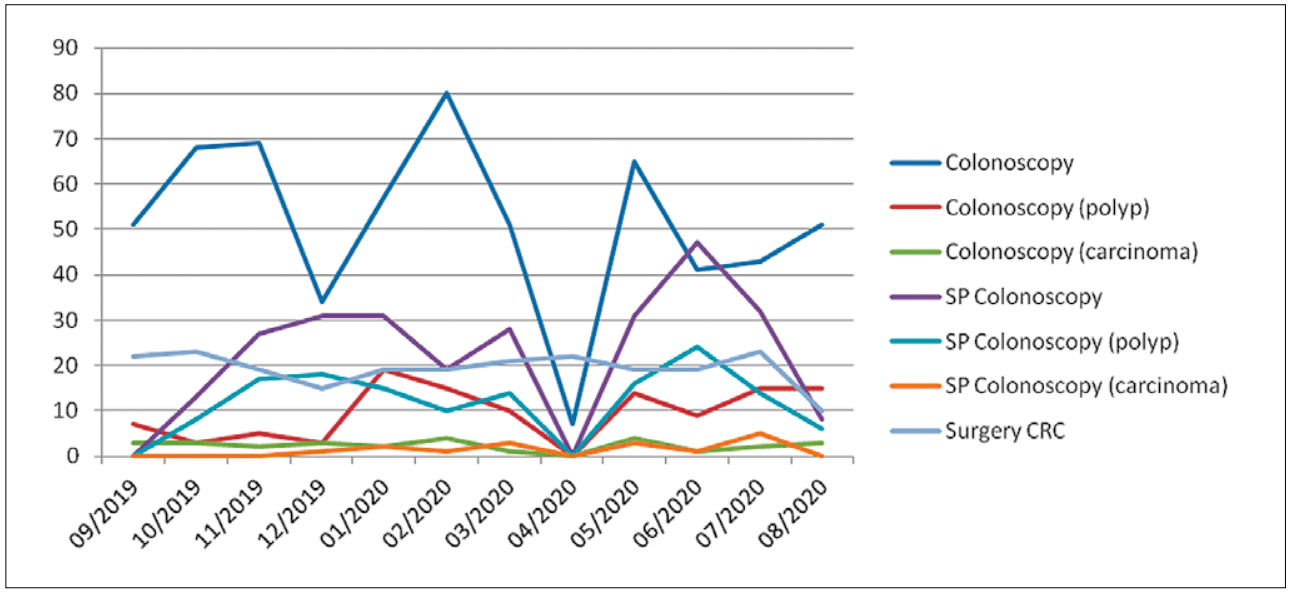

Figure 1. Numbers of colon and rectum related invasive procedures from September 2019 until end of August 2020.

The Croatian colorectal cancer screening program's response rate is not as high as in neighboring European countries, probably an additional parameter for the overall colorectal cancer poor outcomes (4). It is important to stress that most of the curable cases (surgery only) are found in the asymptomatic stage and are mostly caught accidentally or by screening.

Many countries affected by the COVID-19 pandemic recommend rescheduling non-urgent endoscopy procedures or that they should be paused until further notice (5-7).

It is foreseeable that current health restrictions will remain until an indefinite date. Among clinical activities limited by the current restrictions are all screening tests, including colorectal cancer (CRC) prevention procedures.

The pronounced need for targeted screening COVID-19 caused decreased availability in colonoscopy, which includes stratification by a family history on behalf of general practitioners and better compliance to follow up colonoscopy on behalf of prescribing physicians (8-10)

The University Hospital for Tumors, with colorectal cancer treatment, colonoscopy, and screening, is a part of the Croatian referral center for rectal cancer. Since oncological treatment has a significant impact on the Croatian population, early in the COVID-19 proclaimed pandemic situation, the administration retrieved the staff from working on other locations at University Hospital Center and followed the strict measures. Thus maintain the continuity of cancer care.

\section{MATERIAL AND METHODS}

We recorded the number of colonoscopies, screening colonoscopies, tumors, and polyps detected in each group, and colorectal surgeries from August 1'st, 2019, until August 31 ${ }^{\text {st }}, 2020$.

\section{RESULTS}

The number of colonoscopies returned to an average pace after the post-COVID-19 initial peak within three months. Screening colonoscopy oscillated depending on screening waves (FOBT test calls). The number of surgeries remained stable throughout the 12 months (Figure 1).

\section{DISCUSSION}

Colorectal cancer prognosis depends on early, asymptomatic detection and timely treatment.

In most countries on the national level, the delays were considerable, and we expected to note the same at our institution. The answer to the lack of a significant impact on the procedures described during the lockdown probably lies in a short lockdown and the timely transition to $\mathrm{CO}$ VID-19 epidemiological measurement guidelines application. Possibly it is too early to predict the stage and migration of the response rate in the screening programs and impact to the next period, as well this might be impossible to register it. Moreover, most of our patients' admissions (over 
$70 \%$ ) are due to the colonoscopies and confirmed $\mathrm{CRC}$ in other health institutions across Croatia. A small number of patients have been directly drafted from the in-hospital screening programs.

Adequate patient selection for colonoscopies seems to provide a constant proportion of polyp and carcinoma detection. On-site genetic Counseling contributes to screening by selecting family members with a strong history following most national screening policies.

The downside of this data extraction is the lack of context with Croatian national data; more in-depth analysis seemed superfluous as the number is relatively small.

\section{CONCLUSION}

The University Hospital for Tumors maintained colorectal cancer care continuity during the past 13 months, even during the COVID-19 pandemic situation when minor organizational adaptations applied and related to a COVID-19 precolonoscopy or hospitalization patients' swab tests application.

\section{REFERENCES}

1. Šekerija M, Bubanović L, Novak P, Čukelj P, Lončar J, Štruc K, et al. Registar za rak Republike Hrvatske. 2019;(41).

2. Odjel za nacionalne programe probira u odrasloj populaciji I Hrvatski zavod za javno zdravstvo [Internet]. [cited 2020 Oct 16]. Available from: https://www.hzjz. $\mathrm{hr}$ /sluzba-epidemiologija-prevencija-nezaraznih-bolesti/odjel-za-nacionalne-programe-probira-u-odraslojpopulaciji/

3. Lansdorp-Vogelaar I, Karsa L Von. European guidelines for quality assurance in colorectal cancer screening and diagnosis. First Edition Introduction. Endoscopy; 2012; 44(suppl 3 - S03):SE15-30

4. Antoljak N, Šekerija M. Epidemiology and screening of colorectal cancer. Libri Oncol. 2013;41(1-3):3-8.

5. Del Vecchio Blanco G, Calabrese E, Biancone L, Monteleone G, Paoluzi OA. The impact of COVID-19 pandemic in the colorectal cancer prevention. Int $\mathrm{J} \mathrm{Co}^{-}$ lorectal Dis. 2020;35(10):1951-4.

6. Joint gi society message- COVID-19 Clinical Insights for Our Community of Gastroenterologists and Gastroenterology Care Providers [Internet]. [cited 2020 Oct 16]. Available from: https://www.asge.org/home/ joint-gi-society-message-covid-19

7. Health screening programmes paused - gov.scot [Internet]. [cited 2020 Oct 16]. Available from: https:// www.gov.scot/news/health-screening-programmespaused/

8. Advice for Endoscopy Teams during COVID-19. 2020. [Internet]. [cited 2020 October 16th] Available from: https://www.bsg.org.uk/wp-content/uploads/2020/04 /Advice-for-Endoscopy-Teams-during-COVID-ver2-55-final-CLEAN.pdf?x19508

9. Anderson JC, Baron JA, Ahnen DJ, Barry EL, Bostick RM, Burke CA, et al. Factors Associated With Shorter Colonoscopy Surveillance Intervals for Patients With Low-Risk Colorectal Adenomas and Effects on Outcome. Gastroenterology. 2017;152(8):1933-1943.e5.

10. Restivo A, Delrio P, Deidda S, Spolverato G, Rega D, Cerci M, et al. Predictors of Early Distant Relapse in Rectal Cancer Patients Submitted to Preoperative Chemoradiotherapy. Oncol Res Treat. 2020;43(4):146-52. 


\section{Sažetak \\ UTJECAJ COVID-19 EPIDEMIOLOŠKIH MJERA NA RAD HRVATSKOG TERCIJALNOG CENTRA ZA KOLOREKTALNI KARCINOM}

I. Kirac, Z. Misir, V. Vorih, L. Ćurt, M. Šekerija i N. Antoljak

U posljednjih šest mjeseci suočili smo se s kratkom obustavom rada i polaganim povratkom u normalne aktivnosti u većini bolnica u Hrvatskoj. Budući da smo jedina bolnica koja se bavi isključivo liječenjem solidnih novotvorina u Hrvatskoj koja djeluje unutar velikog sveučilišnog bolničkog centra, uspjeli smo održati većinu svojih rutinskih djelatnosti, osim jednomjesečnog obustavljanja kolonoskopija.

Cilj: Odrediti oscilacije rada kroz broj endoskopija i zahvata kolorektalne kirurgije tijekom razdoblja od 13 mjeseci (šest mjeseci prije i nakon zaključavanja COVID-a).

Materijali i metode: koristili smo podatke bolničke analitike za razdoblje od 1. kolovoza 2019. do 31. kolovoza 2020. za broj kolonoskopija, probirnih kolonoskopija (polipektomija i detektiranih karcinoma) te kolorektalnih operacija.

Rezultati: Tijekom određenog razdoblja broj otkrivenih polipa te otkrivenih i operiranih karcinoma debelog crijeva bio je stabilan, osim u travnju kada uglavnom nismo radili kolonoskopije. Oscilacije kolonoskopija u sklopu nacionalnog programa vezane su uz cikluse poziva.

Zaključak: Nakon usvajanja mjera predloženih u smjernicama za kolonoskopije i kolorektalnu kirurgiju i relativno stabilne ukupne epidemiološke situacije, zadržali smo kontinuitet u liječenju karcinoma debelog crijeva tijekom COVID epidemije.

KLJUČNE RIJEČI: kolorektalna kirurgija, kolonoskopija, COVID-19, Hrvatska 